\title{
Statyba
}

\section{STRAINS AND STRESSES OF THREE-LAYER COMPOSITE BARS AND BEAMS}

\author{
J. Bareišis , D. Garuckas , A. Mikulskas \& D. Striukienè
}

To cite this article: J. Bareišis , D. Garuckas , A. Mikulskas \& D. Striukienè (1997) STRAINS AND STRESSES OF THREE—LAYER COMPOSITE BARS AND BEAMS, Statyba, 3:10, 5-11, DOI: 10.1080/13921525.1997.10531677

To link to this article: https://doi.org/10.1080/13921525.1997.10531677

$$
\text { 曲 Published online: } 26 \text { Jul } 2012 .
$$

Submit your article to this journal

Шll Article views: 111 


\title{
TRISLUOKSNIŲ KOMPOZITINIŲ STRYPŲ IR SIJŲ DEFORMACIJOS BEI IৃTEMPIMAI
}

\author{
J. Bareišis, D. Garuckas, A. Mikulskas, D. Striukienė
}

\section{Iૃvadas}

Mūro siena, perdangos plokštė ir kiti konstrukciniai statybų elementai yra daugiasluoksnès konstrukcijos. Vis placiau statybose taikomos ir naujausios kompozitinès medžiagos (KM): stiklo, anglies ar boro plastikai, t.y. medžiagos, kurioms būdingos ryškios anizotropines savybès. Derinant KM stiprumo bei standumo charakteristikas tempimui ar lenkimui su šių medžiagų tankiu ar kaina, galima gauti maksimalaus stiprumo ir standumo bei mažiausios masès ar kainos daugiasluoksnę konstrukciją. Tai ypač svarbu projektuojant statybinès paskirties objektus. Kai kurie daugiasluoksnių kompozitinių sijų tyrimų rezultatai pateikti [1-4] darbuose. Tačiau minètuose darbuose mažai nagrinèti standumy bei įtempimu pasiskirstymo dèsningumai trisluoksniuose konstrukciniuose elementuose.

Šio darbo tikslas yra išnagrinèti tempiamu ar lenkiamų trisluoksnių strypu standumų arba deformacijų bei ịtempimų pasiskirstymų désningumus, keičiant sijos sluoksnių geometrines charakteristikas, medžiagas bei jų išdèstymą strypų skerspjūvyje. Strypu sluoksniai buvo formuojami iš anglies plastiko $(A)$, karšto $\left(S_{k}\right)$ ir šalto $\left(S_{\check{s}}\right)$ kietėjimo stiklo plastikų bei epoksidinès dervos $(D)$. Šiu medžiagu mechaninès ir fizinès savybès pateiktos 1 lentelèje.

\section{Konstrukciniu elementy charakteristika ir ju analitinis skaičiavimas}

Keičiant iš šių medžiagu sudarytu sluoksnių padètis buvo nagrinejamos pirmuju devynių tipu simetrinès konstrukcijos, kurios, naudojant raidinius medžiagu žymèjimus, gali bũti pažymètos:
1. $A-S_{k}-A$
2. $A-S_{\zeta}-A$;
3. $A-D-A$;
4. $S_{k}-A-S_{k}$;
5. $S_{\zeta}-A-S_{\zeta}$
6. $D-A-D$;
7. $S_{k}-S_{\zeta}-S_{k}$;
8. $S_{\zeta}-S_{k}-S_{\zeta}$;
9. $S_{k}-D-S_{k}$;
10. $S_{\zeta}-D-S_{\zeta}$;
11. $D-S_{k}-D$
12. $D-S_{\S}-D$.

Konstrukcijas, kuriose išorinių sluoksnių medžiagos tamprumo modulis $E_{1}$ yra didesnis nei vidurinio sluoksnio $E_{2}$ - vadinsime "tiesioginèmis" $(1,2,3,7$, 9, 10 tipo konstrukcijose $\left.E_{1}>E_{2}\right)$, o jei mažesnis "atvirkštinèmis" $\left(4,5,6,8,11,12\right.$ tipo $\left.-E_{1}<E_{2}\right)$. Šių trisluoksnių konstrukcijų išoriniai sluoksniai pagaminti iš vienos medžiagos, o jų storiai lygūs $\left(\delta_{1}=\delta_{3}\right)$. Buvo naudojami stačiakampio skerspjūvio vienodo pločio bandiniai $(\mathrm{b}=50 \mathrm{~mm})$. Vidurinio ir išorinių sluoksnių storiai buvo keičiami išlaikant bendrą bandinio aukštị pastovų, t.y. $H=\sum \delta_{i}=12 \mathrm{~mm}=$ const. Itempimų ir deformaciju dydžiai buvo skaičiuojami gembinei sijai esant santykiniams apkrovų dydžiams $\mathrm{F}=100 \mathrm{~N}, \mathrm{M}=100$ Nm. Itempimai skaičiuojami pagal formules [5]:

1 lentelè. Medžiagų, naudojamų daugiasluoksneje sijoje, mechaninès ir fizinès savybès, jų sąlyginè kaina Table 1. Mechanical, physical qualities and agreed price of materials used in laminated beam

\begin{tabular}{|l|c|c|c|c|c|}
\hline \multicolumn{1}{|c|}{ Medžiaga } & $\begin{array}{c}\text { Tamprumo } \\
\text { modulis E, GPa }\end{array}$ & $\begin{array}{c}\text { Slyties modulis, } \\
\mathrm{G}, \mathrm{GPa}\end{array}$ & $\begin{array}{c}\text { Stiprumo riba } \\
\text { lenkiant } \sigma_{u_{b}, \mathrm{GPa}}\end{array}$ & $\begin{array}{c}\text { Tankis } \rho^{-10^{3},} \\
\mathrm{~kg} / \mathrm{m}^{3}\end{array}$ & $\begin{array}{c}\text { Kaina, } \\
\text { sall. vnt. }\end{array}$ \\
\hline Anglies plastikas & 60 & 3,0 & 0,775 & 1,9 & 13 \\
\hline $\begin{array}{l}\text { Karšto kietėjimo } \\
\text { stiklo plastikas }\end{array}$ & 20 & 4,5 & 0,775 & 1,75 & 1,4 \\
\hline $\begin{array}{l}\text { Šlto kietèjimo stiklo } \\
\text { plastikas }\end{array}$ & 9 & 0,8 & 0,250 & 1,4 & 1,25 \\
\hline Epoksidinè derva & 1,6 & - & 0,022 & 0,75 & 1,0 \\
\hline
\end{tabular}


esant ašinei apkrovai

$$
\sigma_{z i}=N E_{i} / B,
$$

o veikiant lenkimo įrąžoms

$$
\begin{gathered}
\sigma_{i}=\frac{M_{z}}{D} E_{i} \cdot y, \\
\tau=\frac{Q_{z} \cdot C_{x}}{D \cdot b_{x}} .
\end{gathered}
$$

Bendruoju atveju [6] deformacijos arba įlinkiai:

$$
\begin{aligned}
& V_{z}=V_{o}+\theta_{o} z+\frac{M_{z}}{K}+\sum \frac{M_{i} Z_{m i}^{2}}{2 D}+ \\
& +\sum \frac{F_{i} Z_{f i}^{3}}{6 D}+\sum \frac{q_{i} Z_{q i}^{4}}{24 D} .
\end{aligned}
$$

Siose lygtyse $B$ ir $D$ yra tempiamo (gniuždomo) strypo ir sijos standumai; $C_{x}$ - ekvivalentinis statinis momentas; $K$ - sijos standumas šlyčiai. Šie dydžiai skaiciuojami iš (5)-(8) lygybių [5]:

$$
\begin{gathered}
B=\sum_{i=1}^{n} A_{i} E_{i}, \\
D=\sum_{i=1}^{n} E_{i} I_{i}, \\
C_{x}=\sum_{i=1}^{m} E_{i} \cdot S_{x i}, \\
K=\frac{H \cdot A_{k}}{\sum_{i=1}^{n}\left(\delta_{i} / G_{i}\right)} .
\end{gathered}
$$

\section{Strypu stiprumas ir standumas}

Nagrinëjant trisluoksnių tempiamų (gniuždomų) strypy standumo $B$ priklausomybes nuo vidurinio sluoksnio $\delta_{2}$ santykio su $H$ kitimu, buvo gautos tiesinès priklausomybès, kurių analitinè išraiška yra gaunama iš (5) lygybès;

$$
B=A_{k}\left[E_{1}+\left(E_{2}-E_{1}\right) \psi\right],
$$

čia $\psi=\delta_{2} / H$ - vidurinio sluoksnio santykinis storis; $A_{k}$ - strypo skerspjūvio plotas.

Iš (9) lygybès gauname, kad didèjant $\psi$ strypo standumas didèja "atvirkštinèse" $\left(E_{2}>E_{1}\right)$ ir mažèja "tiesioginèse" $\left(E_{1}>E_{2}\right)$ konstrukcijose. Sių tiesių posvyrio kampo dydis priklauso nuo sluoksnių tamprumo modulių skirtumo, t.y. $\left|E_{2}-E_{1}\right|$. Esant didesnei šio skirtumo reikšmei tiesių posvyrio kampas didèja ir strypo standumas kinta sparčiau. Vienodas standumas arba vienodi linijinių deformacijų dydžiai "tiesioginio" ir "atvirkštinio" tipo strypuose $\left(A-S_{k}-A\right.$ ir $\left.S_{k}-A-S_{k}\right)$ gaunami kai $\psi=0,5$.

Normalinių ịtempių dydžiai tempiamo (gniuždomo) strypo sluoksniuose yra tiesiog proporcingi sluoksnių medžiagų tamprumo moduliams ir atvirkščiai proporcingi strypo standumui $B$ (1 lygtis). Itempių šuolis pereinant iš vieno sluoksnio i kitą yra proporcingas tamprumo modulių skirtumui. Didèjant santykiniam vidurinio sluoksnio storiui $\psi$, itempiai išoriniame $\left(\sigma_{1}\right)$ ir viduriniame $\left(\sigma_{2}\right)$ sluoksniuose vienodu intensyvumu didèja "tiesioginèse" strypu konstrukcijose (t.y. kai $E_{1}>E_{2}$ ) ir mažèja "atvirkštinio" tipo. Abieju tipų strypu sluoksniuose vienodos normalinių įtempių reikšmès gaunamos, kai $\psi=0,5$. Jos yra lygios:

$$
\sigma_{z i}=2 N E_{i} / A_{k}\left(E_{1}+E_{2}\right) \text {. }
$$

İdomu pažymèti, kad skaičiuojant įtempius pagal mūsų metodiką [5] ir baigtinių elementų metodu [7] buvo gauta tik $0,3 \%$ paklaida.

Žinoma, kad ašinio apkrovimo atveju sluoksniuotosiose konstrukcijose atsiranda ir tarpsluoksniniai ịtempiai [8], kurie gali būti suirimo priežastimi, ypač pakraščio zonoje. Darbe [7] taikant baigtinių elementų metodą detaliai išnagrinètos šiu įtempių priklausomybès nuo sluoksnių medžiagos, jų armavimo kampų, sluoksnių išdèstymo. Nustatyta, kad esant tempimo įrąžai racionalu sluoksnius su mažesniu tamprumo moduliu išdèstyti viduryje, o jei yra gniuždymo apkrova - išorèje.

Taigi gauname, kad esant ašinei įrąžai racionaliau naudoti "tiesioginio" tipo strypus su $\psi<0,5$, o gniuždymo atveju - "atvirkštinio" tipo, kai $\psi>0,5$.

\section{Siju standumas ir deformacijos}

Nagrinèjamų stačiakampio skerspjūvio sijų standumo $D$ priklausomybès nuo $\psi$ analitiškai yra aprašomos lygybe

$$
D=I_{k}\left[E_{1}+\left(E_{2}-E_{1}\right) \psi^{3}\right]
$$

ir pateiktos 1 pav. Cia $I_{k}$ - sijos skerspjūvio inercijos momentai.

Iš (11) lygties ir pateiktų kreivių gauname, kad kai išorinio sluoksnio medžiagos tamprumo modulis $E_{1}$ yra didesnis už vidurinio - $E_{2}$ ("tiesioginio" tipo konstrukcija), didèjant $\psi$ sijos standumas mažèja, o 
"atvirkštinio" tipo konstrukcijose $\left(E_{1}<E_{2}\right)$ didèja. Pagal sijos standumo kitimo greitị galime skirti dvi zonas: mažo standumo kitimo greičio, kai $\psi \leq 0,5$, ir didelio - kai $\psi>0,5$. Praktiniu požiūriu ši ypatybè ypač naudinga. Kai sijos vidurinis sluoksnis yra is medžiagos, turinčios mažesni tanki ir standumą, paveiksle $A-S_{k}-A, A-D-A$ tipo sijose, esant vidurinio sluoksnio storiui lygiam pusei sijos skerspjūvio aukšcio, sijos standumas sumažẻja tik 8$12 \%$. Siame intervale yra ir kitu nagrinejjamu sijų standumo sumažèjimas. Tai leidžia ${ }^{-1,8-1,9}$ karto sumažinti $A-S_{k}-A$ ir $A-D-A$ sijų kainą bei $35 \%$ pastarosios tanki. Esant "atvirkštinio" tipo konstrukcijai $\left(E_{1}<E_{2}\right)$, santykiui $\psi$ padidejus iki 0,5 gaunamas didesnis procentinis sijos standumo padidejjimas, nors skaitinès reikšmès tos pačios.

Didžiausias sijų standumo didèjimas - kai santykis $\psi$ mažèja nuo 1,0 iki 0,8 , t.y. įtraukiant ị sijos konstrukciją plonus didelio standumo išorinius sluoksnius. Pavyzdžiui, ant šalto kietejjimo stiklo plastiko užklijavus $1 \mathrm{~mm}$ storio anglies plastiko ar karšto kietèjimo stiklo plastiko sluoksnius (t.y. kai $\psi=84 \%$ ) sijos standumas atitinkamai padidèja $240 \%$ ir $50 \%$. Tas pačias medžiagas užklijavus ant epoksidinès dervos sijos standumas padidèja $154 \%$ ir $485 \%$, o sijos tankis atitinkamai - tik 25 ir $21 \%$.

Siju, pagaminty is tụ pačiu medžiagų, bet skirtingai išdèstytų, standumų kreivés kertasi viename taške, kurių abscisè randama iš sąlygos, kai išorinių sluoksniy inercijos momentas yra lygus vidurinio sluoksnio inercijos momentui, $\left(2 I_{1}=I_{2}\right)$, nes $E_{1}$ ir $E_{2}$ nagrinèjamojoje sijoje nekinta, o siju standumai yra lygūs. Tuomet iš (6) lygybès gauname, kad šį tašką atitinkantis vidurinio sluoksnio storis $\delta_{2}=\sqrt[3]{H^{3} / 2}=0,794 H(\psi=0,8)$. Ivertinus $\psi$ reikšmę, taško ordinatè randama transformavus (11) lygtį:

$$
y_{F}=D_{F}=0,5 I_{k}\left(E_{1}+E_{2}\right) \text {. }
$$

Siju standumo priklausomybę nuo jas sudarančių medžiagu tamprumo modulių santykio $E_{1} / E_{2}$ tyrème kai vidurinio sluoksnio medžiagos tamprumo modulis buvo pastovus $\left(E_{2}=1,6 \mathrm{GPa}\right)$, o išorinio sluoksnio $1,6 \leq E_{1} \leq 60 \mathrm{GPa}$. Skaičiavimų duomenys rodo, kad standumo priklausomybé nuo $E_{1} / E_{2}$ santykio yra išreiškiama lygtimi:

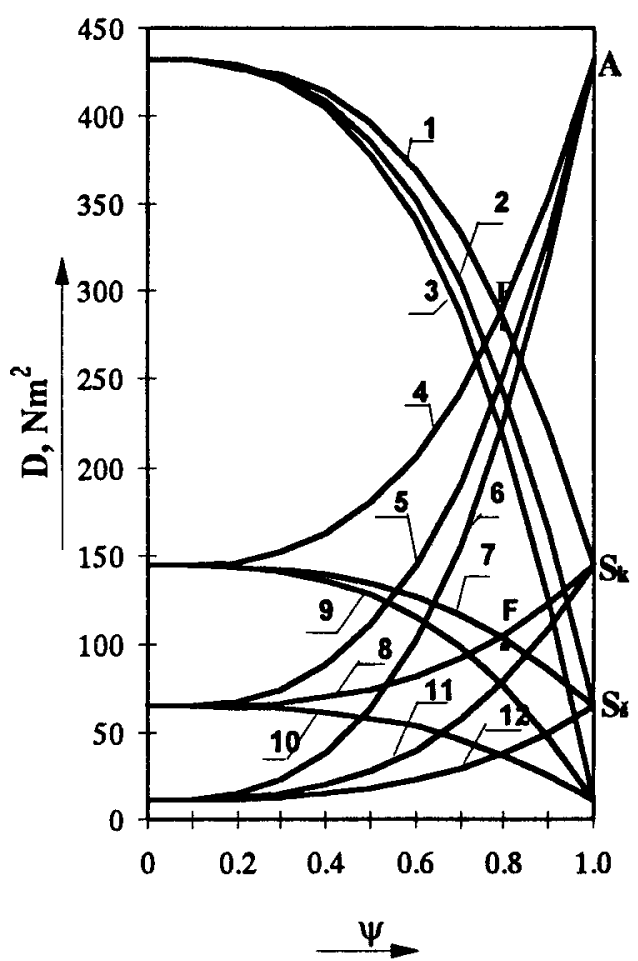

1 pav. Nagrinèjamy sijų standumo kitimo priklausomybé nuo vidurinio sluoksnio santykinio storio $\psi$ (kreiviy žymejjimai atitinka konstrukcijų raidinius žymẻjimus tekste)

Fig 1. Dependency of the changeability upon relative thickness $\psi$ of the middle layer of stiffness of the beam under analysis. (Marking of curves correspond to the characters that mark constructions, referred in the text)

$$
D=I_{k}\left[E_{2}+\left(\frac{E_{2}^{2}}{E_{1}}-E_{2}\right) \psi^{3}\right] \frac{E_{1}}{E_{2}} .
$$

Ivertinus nurodytas tamprumo moduliy ir $\psi$ kitimo reikšmes, laužtiniuose skliaustuose esantis reiškinys kinta nuo 1,6 iki 0,043 . Jo įtaka standumui nedidelè, todèl galime laikyti, kad:

$$
D=C \cdot E_{1} / E_{2} \text {. }
$$

Linijinis sijos standumo kitimas nuo $E_{1} / E_{2}$ yra intensyviausias esant mažoms $\psi$ reikšmèms.

Kadangi sijos standumas $D$ gali būti išreikštas $E_{k} I_{k}$ sandauga, iš (11) lygties galime nustatyti ekvivalentinio sijos tamprumo modulio $E_{k}$ priklausomybę nuo $\psi$ :

$$
E_{k}=E_{1}+\left(E_{2}-E_{1}\right) \cdot \psi
$$

Ši lygtis galioja skaiciuojant tik trisluoksnių konstrukcinių elementų (strypų ir sijų) ekvivalentini tamprumo moduli $E_{k}$, kurị patogu naudoti skaičiuojant standumus $B, D$. 


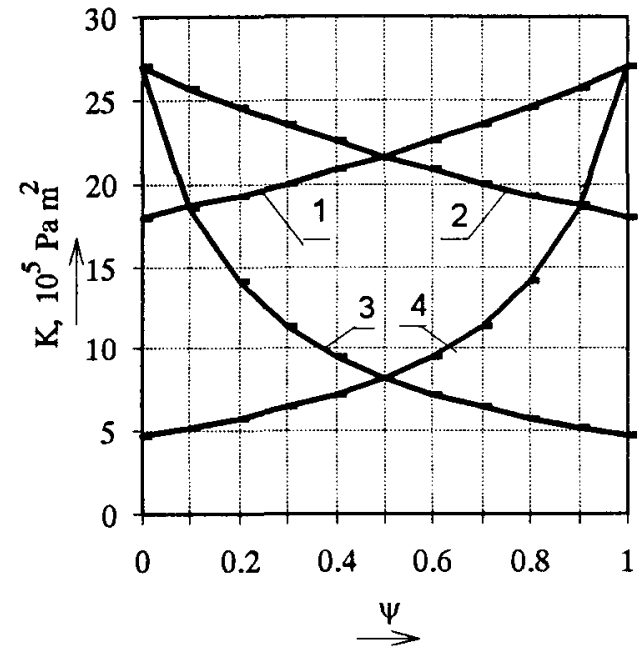

2 pav. Trisluoksnių sijų $A-S_{k}-A$ (1), $S_{k}-A-S_{k}$ (2), $S_{k}-S_{\zeta}-S_{k}$ (3), $S_{\check{S}}-S_{k}-S_{\check{S}}$ (4) standumo šlyčiai $K$ priklausomybès nuo vidurinio sluoksnio santykinio storio $(\Psi)$

Fig 2. Dependencies of three layer beams shear stiffness $K$ upon relative thickness

Skaičiuojant daugiasluoksnių sijų iš kompozicinių medžiagų deformaciją ((4) lygtis), būtina žinoti sijos suñfnach siyuai. Ji skaičiavome pagal formulę (8), panaudoję 1 lentelèje nurodytas šlyties modulio reikšmes.

Trisluoksnių sijų standumo šlyčiai $K$ priklausomybès nuo parametro $\psi$ yra pateiktos 2 pav. Ǐs pateikty duomenu matyti, kad skiriasi standumy $D$ ir $K$ kreivių kitimo pobūdis ir jų skaitinių reikšmių dydžiai. Dèl skirtingu geometrinių charakteristiku standumo šlyčiai K skaitinès reikšmès yra daugiau nei $10^{3}$ kartų didesnès negu $D$. Gautos simetrinių trisluoksniu sijų standumo šlyčiai K priklausomybès nuo parametro $\psi$ aprašomos lygtimi:

$$
K=\frac{A_{k} \cdot G_{1} G_{2}}{\psi G_{1}+(1-\psi) G_{2}} .
$$

Iš gautos lygybès ir 2 pav. matyti, $\mathrm{kad}$ "tiesioginio" ir "atvirkštinio" tipo sijoms, kai $\psi=0,5$, gaunami vienodi standumai. Gavome, kad kai išorinio sluoksnio medžiagos šlyties modulis yra didesnis nei vidurinio, didejant santykiui $\psi$ sijos standumas $K$ ir $D$ mažèja skirtingu intensyvumu. Kai $\psi=0,5$, sijos $S_{k}-S_{\xi}-S_{k}$ standumas $D$ sumažèja $13 \%$, o standumas šlyčiai sumažèja daugiau nei 3 kartus ir sudaro $85 \%$ viso standumo $K$ pokyčio. Be to, čia tikslinga priminti, kad kai kurių medžiagų šlyties modulis $G$, palyginti su tamprumo moduliu $E$, yra ypač mažas (pvz., anglies plastikas ir karšto kietėjimo stiklo plastikas). Šiuo atveju ypač racionalu konstruoti $A-S_{k}-A$ tipo siją su $\psi=0,5$. Tuomet jos standumas $D$ sumažèja, palyginti su gryno anglies plastiko sija, tik $12 \%$, o standumas šlyčiai $K$ padidejja $40 \%$. Keičiant atskiru sluoksnių pločius, standumas $K$ kinta pagal tai, kiek kartų kinta skerspjūvio plotas $A_{k}$. Visa tai rodo, kad varijuojant medžiagų, turinčių skirtingas standumų charakteristikas, išèstymą, galima gauti optimalių standumų sijas.

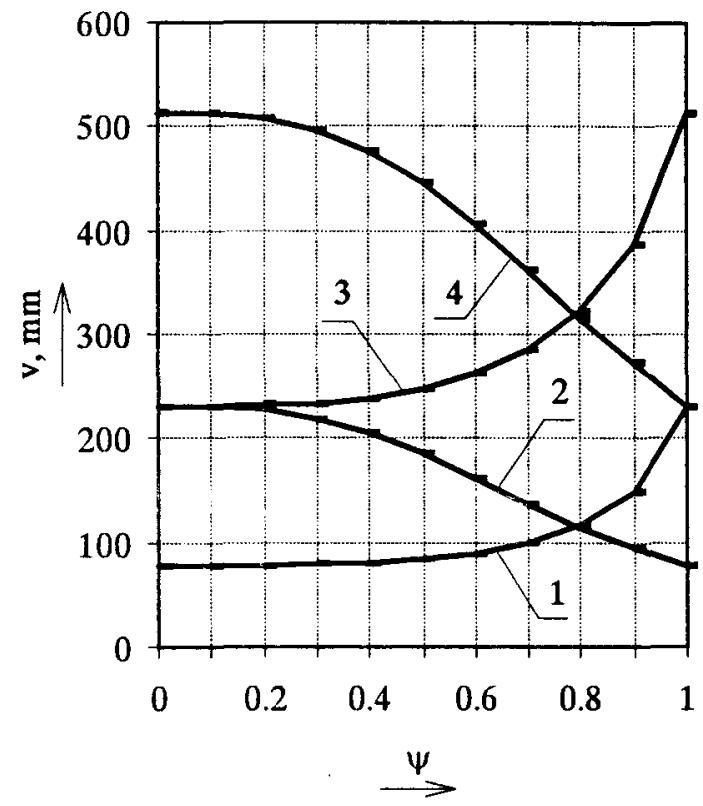

3 pav. Trisluoksniu sijų jlinkio priklausomybès nuo parametro $\Psi$. Kreivių žyméjimai tokie pat, kaip 2 pav.

Fig 3. Dependencies of three layer beams bend upon parameter $\Psi$. Marking of curves is the same as in Fig 2

Atsižvelgiant ị tai, kad gembinè sija, apkrauta koncentruota jèga, nagrinėjamų sijų įlinkiai (deformacijos) buvo skaiciuojami pagal formulę (4) be jos paskutiniojo nario.

Iš 3 pav. pateiktų sijų įlinkio priklausomybių nuo $\psi$ matyti, kad didejjant vidurinio sluoksnio storiui deformacijos dideja "tiesioginio" ir mažèja "atvirkštinio" tipo sijose, t.y. kinta atvirkščiai proporcingai standumui $D$. Sių tipu sijų vienodi illinkiai gaunami kai $\psi=0,8$. Tai rodo, kad didžiausią îtaką nagrinejamų sijų deformacijoms turi standumas $D$. Analitiniai skaičiavimai rodo, kad standumo slyčiai $K$ 
¡taka ilinkiui yra nedidelè. Formulèje (4) praleidus treciaji narị apskaičiuotas ịlinkis pakinta simtosiomis milimetro dalimis. Tai paaiškinama jau minètais standumo šlyčiai skaitinių reikšmių dydžiais. Taigi ịvertinę standumu ir deformaciju kitimus galime teigti, kad panaudojus trisluoksnę $A-S_{k}-A$ tipo konstrukcija, kai jos vidurinio sluoksnio storis lygus 0,5 sijos aukščio, palyginti su sija is anglies plastiko, gaunama $42 \%$ pigesnè ir $4 \%$ lengvesnè konstrukcija, o jos deformacijos padideja vos $4,5 \%$.

\section{5. İtempiai trisluoksnèse sijose}

Keiciant sijos sluoksnių standumą ir jų išdèstymą, keičiasi ne tik sijos standumai, bet ir įtempių dydžiai sijos sluoksniuose (4 pav.). Nurodytos ittempių reikšmès yra apskaičiuotos, kai $M=100 \mathrm{Nm}$ ir $\psi=0,8$, t.y. esant vienodam "tiesioginio" ir "atvirkštinio" tipo sijų standumui $D$.
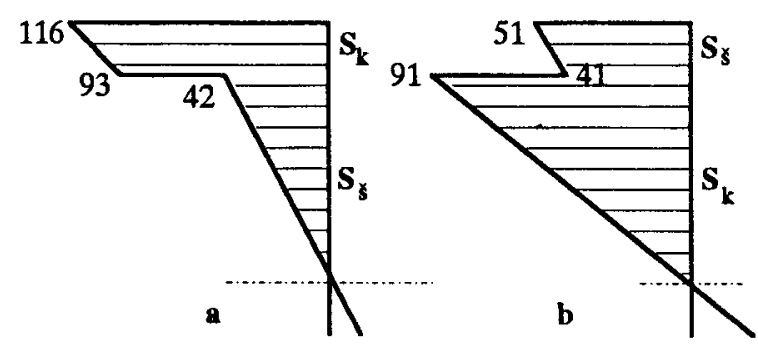

127

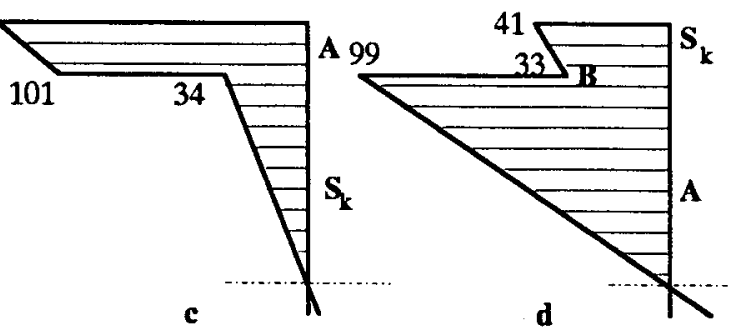

4 pav. Normalinių itempių pasiskirstymas trisluoksnèse 7 (a); 8 - (b); 1 - (c); 4 - (d) - tipo sijose

Fig 4. Distribution of normal tensions in 7, 8, 1, 4 type three layer beams

Iš pateiktų skaitinių reikšmių ir (2) lygties matyti, kad naudojant tas pačias medžiagas (4 pav., a ir b) maksimalūs îtempiai išoriniame sluoksnyje $\left(\sigma_{1}\right)$

yra proporcingi to sluoksnio medžiagos tamprumo moduliui:

$$
\sigma_{1}=\frac{M}{2 D} E_{1} H
$$

Išorinio sluoksnio kontakto zonoje su viduriniu itempis

$$
\sigma_{1}^{\prime}=\sigma_{1} \cdot \psi
$$

Itempis, atsirandantis viduriniame sluoksnyje jo kontakto zonoje su išoriniu

$$
\sigma_{2}=\sigma_{1} \cdot \frac{E_{2}}{E_{1}} \cdot \psi
$$

Idomu pažymèti, kad didesnio standumo medžiagą iš išorinio sluoksnio perkèlus i vidurini, pvz., $A-S_{k}-A$ ir $S_{k}-A-S_{k}$ tipu sijose, itempiai toje pačioje medžiagoje (šiuo atveju anglies plastike) sumažèja $20 \%$, o iš vidurinio perkèlus $\mathfrak{i}$ isororini (šiuo atveju stiklo plastike) tuo pačiu dydžiu padidèja. Tokie ittempių pasikeitimai gauti visy tipy nagrinejjamose sijose. Tai paskatino susidomèti, nuo ko priklauso siu ịtempių pokytis. Tuo tikslu ịtempius "tiesioginio" $\left(A-S_{k}-A\right)$ tipo sijos isoriniame ir viduriniame sluoksnyje ju kontakto zonoje pažymèjome $\sigma_{1}$ ir $\sigma_{2}$, o "atvirkštinio" $\left(S_{k}-A-S_{k}\right)$ tipo sijoje $-\sigma_{i}$ ir $\sigma_{2}^{*}$. Tuomet itempiu pokyčio vienoje medžiagoje (pvz., anglies plastike) dydžiu $\left(\sigma_{1}-\sigma_{2}^{*}\right)$ arba $\left(\sigma_{i}^{*}-\sigma_{2}\right)$ - stiklo plastike $\left(S_{k}\right)$ santykis su $\sigma_{1}$ arba $\sigma_{1}^{*}$ randamas iš lygybès:

$$
\frac{\sigma_{1}-\sigma_{2}}{\sigma_{1}}=\frac{\sigma_{1}^{*}-\sigma_{2}}{\sigma_{1}^{*}}=1-\psi \text {. }
$$

Ši priklausomybè gauta iš (2) ir (12) lygcių, kai "tiesioginio" ir "atvirkštinio" tipo sijų standumai yra vienodi.

Gautoji (19) lygtis pagal ịtempių duomenis vieno tipo sijose ir sluoksnių storius leidžia apskaiciuoti îtempių pokyčius "atvirkštinèje" sijoje.

Normaliniu ittempiy sijos sluoksniuose kitimo priklausomybès nuo santykio $\psi$ pateiktos 5 pav.

Esant "tiesioginio" tipo sijai, paveiksle $A-S_{k}-A$, didèjant vidurinio sluoksnio storiui $\delta_{2}$, ịtempių dydžiai eksponentił̌kai didèja išoriniame (1 kreivè 5 pav.) bei viduriniame sluoksniuose (4 kreivè). Tai susiję su sijos standumo mažèjimo priklausomybe nuo $\psi(1$ pav.). Todèl įtempių kitimo intensyvumui galime išskirti dvi anksčiau minètas greičio zonas. Naudojant "tiesioginio" tipo sijas $\psi$ didejjant iki 0,50 įtempiai padidèja tik 9-14\%. "Atvirkštinio" tipo sijose, kai $E_{1}<E_{2}$ (paveiksle $S_{k}-A-S_{k}$ ), didèjant santykiui $\psi$, normaliniai 
ittempiai išoriniame sijos sluoksnyje $\left(\sigma_{1}^{*}\right)$ mažèja (3 kreive 5 pav.), o viduriniame - $\left(\sigma_{2}^{*}\right)$ didèja ( 2 kreivè).

Sių kreiviu kitimo intensyvumai yra skirtingi, nes itempiai išoriniame sluoksnyje $\left(\sigma_{1}^{*}\right)$ kinta atvirkščiai proporcingai sijos standumo $D$ kitimui (17 lygtis), o vidurinio sluoksnio maksimaliu įtempiu $\left(\sigma_{2}^{*}\right)$ kitimas yra lètesnis ir turi ekstremumą, nes $\left(\sigma_{2}^{*}\right)$ yra dvieju kintamuju $\psi$ ir $D$ funkcija (18 lygtis). Šios 2 ir 3 kreivès kertasi taške $C$ ( 5 pav.), kurio abscisè $\Psi_{c}=E_{1} / E_{2}$. Šiame taške "atvirkštinio" tipo sijos $\left(E_{2}>E_{1}\right)$ išorinio ir vidurinio sluoksnio maksimalūs įtempiai yra lygūs, kai vidurinio sluoksnio storio koeficientas $\psi$ bus lygus šiuos sluoksnius sudaranciu medžiagų tamprumo modulių santykiui $\left(E_{1} / E_{2}\right)$.

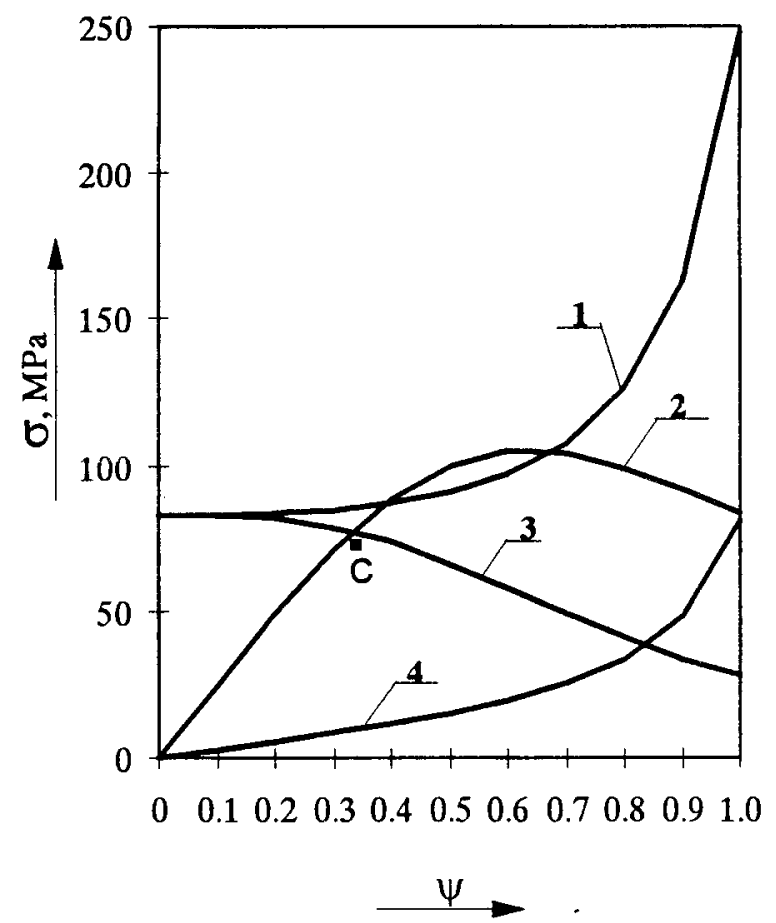

5 pav. Normalinių įtempių kitimas pagal $\psi$ " tiesioginio" (1,

4) ir "atvirkštinio" $(2,3)$ tipo sijų išoriniame $(1,3)$ ir viduriniame $(2,4)$ sluoksniuose

Fig 5. Changing of normal tensions depending on $\psi$ in exterior and middle layers of "direct" and "opposite" types of beam

$A-S_{k}-A$ tipo trisluoksnès konstrukcijos su vidurinio sluoksnio storiu $\delta_{2}=0,5 H$ duomenis palyginę su gryno anglies plastiko sijos parametrais gauname, kad $A-S_{k}-A$ sija yra $42 \%$ pigesnè, $4 \%$ lengvesnè, standumas $D$ sumažèja $12 \%$, standumas šlyčiai $K$ padideja $40 \%$, maksimalios normaliniu įtempių reikšmès padidèja $9 \%$, o deformacijų - 4,5\%.

Pagal formule (3) skaičiuojant tangentinius ịtempius sluoksnių sandūroje nèra šuolio, kuris gaunamas skaiciuojant redukuoto skerspjūvio metodu [9]. Tačiau pereinant iš vieno sluoksnio ị kitą keičiasi tangentiniy ittempiy kitimo intensyvumas. Ypac pavojingas gali būti "atvirkštinio" tipo sijose, kada didesnis vidurinio sluoksnio standumas. Būtina atsižvelgti $\mathfrak{i}$ tangentiniu ịtempių dydžius naudojant medžiagas su mažu atsparumu šlyčiai (pvz., anglies plastiką). Darbe [10] pateikti duomenys, kad sluoksnių kontakto zonoje smarkiai kinta svarbiausiuju įtempių dydžiai ir svarbiausiujų plokštumų krypčių kampai, turintys esminès įtakos trisluoksniy sijų atsparumui. Šiuo metu atliekami detalūs ịtempių ir deformaciju būvio tyrimai kontakto plokštumoje naudojant baigtinių elementu metodą.

\section{Išvados}

1. Gautos lygtys, aprašančios standumy $D$ ir $K$ bei normalinių itempiy kitimą trisluoksniuose strypuose ir sijose pagal santykinio vidurinio sluoksnio storio $\psi$. Strypu ir siju standumo kitimą aprašančios lygtys (9), (11) yra analogiškos savo išraiška, bet skiriasi geometrinèmis charakteristikomis bei koeficiento $\psi$ laipsnio rodikliu.

2. Trisluoksniu konstrukcinių elementu standumo kitimo intensyvumas priklauso nuo sluoksnius sudarančių medžiagu tamprumo modulių bei ju skirtumo $\left|E_{2}-E_{1}\right|$. Jei šis skirtumas teigiamas, didèjant santykiui $\psi$ strypo ir sijos standumai didèja, ir mažèja, kai $E_{2}<E_{1}$.

3. Sijų, kurių $E_{2}>E_{1}$, išorinio ir vidurinio sluoksniı maksimalūs įtempiai yra lygūs, kai santykis $\psi$ lygus santykiui $E_{1} / E_{2}$. Itempiu pasikeitimo vienoje medžiagoje dydžių santykis pereinant iš "tiesioginio" $\left(E_{1}>E_{2}\right)$ i "atvirkštinio" $\left(E_{1}<E_{2}\right)$ tipo sijas yra lygus $1-\psi$, kai šiu sijų standumai yra vienodi.

4. $A-S_{k}-A$ tipo trisluoksnè konstrukcija, kai $\psi=0,5$, gaunama $42 \%$ pigesnè, $4 \%$ lengvesnè, palyginti su anglies plastiko sija, maksimaliu normalinių ịtempių reikšmés padidèja $9 \%$ ir deformacijų - 4,5\%. 


\section{Literatūra}

1. J.Bareišis, A.Mikulskas. Penkiasluoksniq siju standumo ir stiprumo tyrimai // Mechanika, 1995, Nr. 1, p. 25-29.

2. В.В.Васиљев. Механика конструкций из композиционных материалов. Москва: Машиностроение, $1988.772 \mathrm{c}$.

3. И.П.Барейшис, А.П.Микульскас, В.В.Паулаускас. Сопротивляемость трехслойной конструкщии статическому и циклическому изгибу // Механика композитных материалов, 1986, № 5, с. 879-882.

4. L.C.Bank. Shear Coefficients for Thin-Walled Composite Beams // Composite Structures, V.8, 1987, p. 47-61.

5. J.Bareišis. Konstrukciniu kompozity statinis ir ciklinis stiprumas: Habilitacinis darbas. Kaunas, 1995. 106 p.

6. В.В.Васильев, В.Д.Протасов и др. Композиционные материалы: Справочник. Москва: Машиностроение, 1990. c. 512.

7. V.Senkus. Sklandytuvo kompozicinių konstrukcijų atsparumo prognozavimas: Daktaro disertacija. Kaunas, 1996. $141 \mathrm{p}$.

8. H.Rapp. Non homogenous bars under tention, pure bending and thermal loads // Composites Science and Technology, Vol. 44, 1992, p. 21-28.

9. С.П.Тимощенко, Дж.Гере. Механика материалов. М.: Мир, 1976. 669 c.

10. Й.П.Барейшис, А.П.Микуљьскас, В.АКаминскас. Влияние толщины клесвого слоя на сопротивляемость изгибу трехслойной конструхции // Прочность и долговечность. Механическая технология. T. 13. V.: Pauge, 1983, c. 53-63.

11. В.АРадионова, Н.А.Фомина. Точное решение и программа распета на прочность трехслойния шарнирно опертой балхи // Вестник ЛГУ. Серия мат., мех., астрон. Л., 1995.

Iteikta 19970220

\section{STRAINS AND STRESSES OF THREE - LAYER COMPOSITE BARS AND BEAMS}

\section{J.Bareišis, D.Garuckas, A.Mikulskas, D.Striukienė}

S u m m a ry

New composite anisotropic materials (CM) glass, carbon and boric plastics are more and more frequently used in engineering construction. By tuning strength and stiffness characteristics of CM under tension or bending with their density or price it is possible to get laminated construction of maximum strength and stiffness and minimum mass or price.
The purpose of this work is to analyse regularity of distribution of stiffness or strains and stresses in threelayer bars, subjected to tension or bending by changing geometric characteristics of layer, materials and their position in cross-section of bars. The bar layers were formed of carbon plastic $(A)$, hot $\left(S_{k}\right)$ and cold hardening $\left(S_{c}\right)$ glass plastics and epoxy resin $(D)$.

Equations were obtained describing the alteration of bar and beam stiffness and the alteration of normal stresses, all depending on relative thichness $\Psi$ of bar or beam. The relative thickness $\Psi$ is the ratio of middle layer height to the whole height.

It has been shown that maximum stresses in exterior and middle layers ( with elasticity modules $E_{1}$ and $E_{2}$ accordingly) become equal when $\Psi=E_{1} / E_{2}$. The intensity of stiffness alteration depends on the magnitude of $\mid E_{2}-$ $E_{1} \mid$. In the case of positive magnitude, the bar or beam stiffness increases while increasing $\Psi$. In the opposite case the stiffness decreases with decrease of $\Psi$.

For the example of structure $A-S_{k}-A$ and $\Psi=$ 0,5 , the price economy for $42 \%$ and mass reduction for $4 \%$ have been shown and compared with carbon plastic beam.

Jonas BAREIŠIS. Professor, Doctor Habil. Kaunas University of Technology (KTU). Panevèžys Polytechnic Faculty. Research interests: the strength and fracture investigations of plastic, composite materials and make up from it's laminated structural elements, effected by static and cyclic loading.

Danas GARUCKAS. MSc working on doctoral thesis at KTU. Research interests: investigation into strength, stress and strain of laminated structural elements into.

Alvydas Antanas MIKULSKAS. Senior Assistant KTU Panevėżys Polytechnic Faculty. Research interests: static and cyclic strength of materials.

Danguolè STRIUKIENE. Assistant. KTU Panevèžys Polytechnic Faculty. Research interests: laminated structural elements. 